\title{
QUO VADIS USAHA KECIL DAN MENENGAH DI INDONESIA
}

\author{
Rina Yuliastuty Asmara \\ Dosen Universitas Bunda Mulia, Jakarta \\ Email: rina_asmara@bundamulia.ac.id
}

\begin{abstract}
Abstrak: Selama krisis ekonomi, Usaha Kecil dan Menengah / UKM terus berkembang dan kelihatannya mampu bertahan dan beradaptasi dengan lingkungan usaha besar. Selama tahun 2000 (setelah krisis) jumlah Usaha Kecil yang telah ada berjumlah 39 juta unit sedang usaha menengah 55 ribu unit dimana keduanya menyerap tenaga kerja 74,3 juta pekerja atau $99,4 \%$ dari total pekerja yang ada. UKM juga memberikan kontribusi yang sangat signifikant dalam GDP, yaitu $56,7 \%$ dari total GDP yang terdiri dari 40\% dari Usaha Kecil dan 16,3\% dari Usaha Menengah.
\end{abstract}

Kata Kunci: Usaha Mikro Kecil dan Menengah, perekonomian Indonesia

\section{Permasalahan UMKM}

Menurut Prof. Dr. Urata (2000) terdapat beberapa masalah yang dihadapi usaha kecil, yaitu : aspek kebijakan, aspek keuangan, aspek non keuangan, aspek administrasi. Aspek Kebijakan, merupakan suatu masalah mendasar yang harus dibenahi dalam pengembangan usaha kecil dan menengah/UKM. Keberpihakan pada UKM sudah jelas tertera pada pembukaan dan pasal 33 UUD 45, GBHN 1998 dan 1999, Tap MPR no. XVI/1998 tentang demokrasi ekonomi, UU pengusaha kecil. Kemudian bila dikaitkan dengan adanya otonomi daerah, maka pemangkasan hambatan birokrasi diharapkan dapat merangsang pemain-pemain lokal. Kepastian hukum, keamanan dan faktor lingkungan usaha yang kondusif harus diciptakan dan dipelihara.

Aspek keuangan, khususnya permodalan adalah masalah yang paling utama dan dominan dihadapi oleh usaha kecil di Indonesia, mengingat akses rakyat kecil terhadap aset produksi yang dimiliki negara sangat terbatas. Penguatan terhadap lembaga-lembaga keuangan yang mengkhususkan diri untuk UKM, seperti BPR, BMT,KSP dan lain sebagainya harus terus dilakukan. Bimbingan teknis dan finansial kepada lembaga-lembaga keuangan tersebut harus dirumuskan dalam skala nasional. Pelaku UKM juga meng-upgrade pengetahuannya dalam mengenal dan memahami cara mengakses lembaga keuangan tersebut, khususnya terhadap syarat-syarat yang harus dipenuhi untuk masalah kepercayaan, aspek legal formal.

Aspek Non keuangan, terdiri dari beberapa aspek, yaitu antara lain :

- Tidak berkembangnya suporting industries.

- Kurang mampunya memanfaatkan fungsi pada sentra-sentra yang potensial.

- Tidak sesuainya jasa layanan yang diberikan pemerintah dengan kebutuhan UKM.

- Kurangnya informasi pasar luar negeri.

- Kurangnya kredit ekspor yang disediakan bank-bank komersial.

- Kurangnya SDM untuk pengembangan ekspor.

Aspek administrasi,meliputi beberapa hal :

- Kurangnya koordinasi kebijakan pengembangan UKM.

口 Definisi UKM yang berbeda / bervariasi antar instansi

Dari beberapa aspek masalah yang dihadapi oleh usaha kecil dan menengah, maka aspek keuangan / permodalan merupakan aspek yang paling banyak dijumpai / ditemui.

Dan Steinhoff dan John F Burgess dalam bukunya Small Business Management Fundamental, menyebutkan setiap usaha baru harus dapat menjawab 3 pertanyaan tentang masalah finansial I keuangan, yaitu : Berapa banyak dana yang dibutuhkan? Dari mana dana tersebut diperoleh? Kapan dana tersebut dibutuhkan?. Masih menurut Dan Steinhoff dan John F Burgess, terdapat beberapa sumber dana yang dapat diperoleh untuk usaha kecil (sesuai kondisi masyarakat AS \& Eropa), yaitu :

a. Personal funds : Merupakan modal sendiri yang harus ditanamkan / diinvestasikan untuk memulai usahanya.

b. Loans from relatives and friends : Merupakan modal yang diberikan oleh teman, yang dapat berupa pinjaman uang secara murni atau teman menginvestasikan modallnya pada usaha / bisnis yang kita jalankan. 
c. Trade or business-to business credit from suppliers : Merupakan pemberian atau suntikan modal yang terjadi karena supplier besar menitipkan barangnya kepada kita dan pembayarannya dilakukan dibelakang hari. Hal ini sangat meringankan cash flow usaha kecil kita

d. Loans or business to business credit from equipment sellers : Merupakan pembelian barangbarang pendukung produksi seperti : mesin, furniture, kendaraan, komputer, dll yang pembayarannya dilakukan secara angsuran. Hal ini memberi dampak kepada meningkatnya likuiditas dan meringankan beban cash flow.

e. Mortage loans : Merupakan pinjaman yang dapat diperoleh bila membeli lahan usaha secara kredit, seperti memperoleh kredit perumahan (mortage credit) yang memiliki jangka waktu angsuran 20 - 30 tahun,

f. Commercial bank loans : Merupakan dana yang disediakan oleh bank komersial terhadap usaha kecil, walaupun tidak semua bank komersial menyediakan skem kredit tersebut. Bank yang mengucurkan kredit kepada usaha kecil umumnya sangat formal, sementara disisi lain usaha kecil tidak / kurang memiliki persyaratan formal.

\section{Sumber Pembiayaan UKM di Indonesia}

Kerangka kebijakan pemberdayaan usaha kecil dan menengah terdapat pada pembukaan dan pasal 33 UUD 45, GBHN 1998 dan 1999, Tap MPR no.XVI/1998 tentang demokrasi ekonomi, UU pengusaha kecil, UU persaingan yang sehat. Masalah permodalan untuk UKM di Indonesia, juga di negaranegara berkembang lainnya merupakan masalah utama yang harus segera diselesaikan. Ciri utama negara berkembang, (umumnya merdeka setelah Perang Dunia II) :

a. Rendahnya kualitas pendidikan/sumber daya manusia

b. Rendahnya tingkat kesehatan masyarakat

c. Tingginya tingkat angka kelahiran penduduk

d. Tingginya tingkat angka kematian penduduk

e. Tingginya pengangguran

f. Rendahnya akses masyarakat ke faktor-faktor produksi

g. Rendahnya tabungan masyarakat

Dari ciri-ciri masyarakat negara berkembang diatas diperburuk lagi oleh faktor-faktor lain yang tidak mendukung seperti telah dikemukakan diatas. Kondisi sosial, ekonomi dan politik di Indonesia sangat berbeda dengan negara-negara maju yang umumnya menganut sistem kapitalis (AS dan Eropa) serta memiliki sejarah panjang budaya yang berbeda dengan Indonesia. Untuk kondisi Indonesia, terdapat beberapa lembaga yang secara khusus memberikan bantuan permodalan untuk usaha kecil, antara lain :

- Bank Rakyat Indonesia, Bank umum komersial (BNI 46, Danamon, Bukopin).

- Bank perkreditan rakyat yang terdapat di seluruh Indonesia (kecamatan).

- PT. Permodalan Nasional Madani (PT.PNM), Lembaga keuangan syariah dan koperasi

PT.PNM (persero) didirikan berdasarkan PP No.38/99 tanggal 25 Mei 1999. Salah satu fungsi pokok PNM tertuang dalam SK Menteri Keuangan RI no.487/KMK.017/1999 tanggal 13 Oktober 1999 yang menetapkan PNM sebagai salah satu BUMN koordinator penyalur kredit program eks KLBI yang sebelumnya dilaksanakan oleh Bank Indonesia. Tugas utama PNM adalah memberikan solusi pembiayaan pada usaha kecil dan menengah dengan kemampuan yang ada berdasarkan kelayak usaha serta prinsip ekonomi pasar. Fokus usaha yang dikembangkan antara lain sektor agribisnis yang terdiri dari bidang pangan, perkebunan, perikanan, peternakan, kehutanan , industri rumah tangga yang berorientasi ekspor, padat karya dan menghasilkan nilai tambah, disamping sektor jasa seperti pengembang, pariwisata dan tenaga kerja. Nilai tambah yang dimaksud menyangkut konsep dagang, pemanfaatan teknologi dan kualitas produk. Dalam operasionalnya PNM menggunakan jasa lembaga keuangan yang telah ada atau yang khusus dibentuk untuk itu, seperti bank umum, bank perkreditan rakyat (syariah), Induk koperasi simpan pinjam, Lembaga modal ventura atau lembaga-lembaga laian yang tersebar di seluruh Indonesia.

Sumber pembiayaan yang disalurkan PNM berasal dari modal pemerintah dan kini dalam penjajakan untuk memperoleh modal dari dalam dan luar negeri. Sumber pembiayaan yang berasal dari investor lokal dan luar negeri dapat dihimpun oleh PNM melalui dana investasi PMN Investment Management. Disamping itu, PNM juga dibebani oleh misi pemerataan pemilikan asset produktif (redistribusi asset produktif) dalam rangka kemandirian ekonomi nasional dan pemilikan aset nasional oleh UKMK yang saat ini sedang dalam tahap persiapan.

Uraian diatas merupakan pandangan dari sisi pemerintah dan lembaga pemberi bantuan kepada usaha kecil dan menengah. Bagaimana pandangan pelaku usaha kecil dan menengah itu sendiri? Menurut Pandu Suharto (1997), bila masyarakat pedesaan memiliki dana maka 30\% untuk menambah modal 
usaha, 30\% untuk membeli emas, perabot dll, 23,33\% disimpan dirumah, 13,33\% disimpan di Bank dan $13,34 \%$ dipinjamkan ke saudara, tetangga, kerabat.

Sementara itu pertimbangan yang menyebabkan masyarakat pedesaan menabung di bank adalah :

\begin{tabular}{|c|c|c|c|}
\hline ALASAN & PETANI & NELAYAN & PEDAGANG \\
\hline Tingkat bunga & $\overline{16,67 \%}$ & $0 \%$ & $3,85 \%$ \\
\hline Prosedur (tarik/ambil) & $60 \%$ & $82,8 \%$ & $1,54 \%$ \\
\hline Jaminan kembali & $23,44 \%$ & $3,3 \%$ & $90 \%$ \\
\hline Lainnya (sosial) & $0 \%$ & $13,9 \%$ & $7,69 \%$ \\
\hline
\end{tabular}

Dari data-data diatas terlihat bahwa pertimbangan utama masyarakat pedesaan untuk menabung di bank bukan karena faktor suku bunga yang tinggi, tapi karena prosedur yang mudah dan keamanan pengembalian dana. Untuk itu, adanya lembaga keuangan yang membidik UsahaKecil dan Menengah tidak menjamin lancarnya pembiayaan UKM bila tidak disertai dengan pemahaman terhadap kebutuhan dan keperluan UKM itu sendiri.

\section{REFERENSI}

Urata (2000), Policy Recomendation for SME Promotion in Republic Indonesia, 26 Juli 2000.

SK Direktur Bank Indonesia No. 31/143/KEP/DIR pada tanggal 12 November 1998 tentang PPAP.

SK Menkeu RI No. 487/KMK.017/1999 tanggal 13 Oktober 1999.

Urusan Kredit Bank Indonesia, Statistik Kredit Koperasi \& Kredit Usaha Kecil (KUK), Maret 1998. 